\title{
Democratic Legitimacy and Non-Majoritarian Institutions: Reflections on the Functional and Democratic Legitimacy of International Adjudicative Bodies and Independent Regulatory Agencies
}

\section{Alain Zamaria"}

\section{Introduction}

The growing role of international adjudicative bodies, regulatory agencies driving public policies in areas such as telecommunications, health, energy and antitrust, and independent central banks running monetary policies are among the numerous signs of the empowerment of non-majoritarian institutions ("NMIs") that carry out public policy without being accountable to the people through electoral and political processes. ${ }^{1}$ Despite being subject to tighter procedural rules, their development is increasingly raising questions of legitimacy as they are, just like "conventional" political authorities, blamed for not having delivered the promises that justified their creation.

In In Whose Name? A Public Law Theory of International Adjudication, Armin von Bogdandy and Ingo Venzke reconsidered the basic purposes of one particular type of NMIs: international jurisdictions. ${ }^{2}$ Claiming that neither the original consent nor the functional goal is sufficient to settle their legitimacy and representation concerns convincingly, the authors tried to find universal standards for the democratic legitimacy of these institutions. The frontier between universalism and skepticism being thin, ${ }^{3}$ "any contribution that purports to be conceived as universal should be

* Research Fellow, Max Planck Institute Luxembourg for Procedural Law.

1 Majone, G. (1999), “The Regulatory State and Its Legitimacy Problems”, West European Politics 22(1), 1-24, 10.

2 Von Bogdandy, A. and Venzke, I. (2014), In Whose Name?: A Public Law Theory of International Adjudication. Oxford: Oxford University Press.

3 On the search for a common ground between universalism and skepticism, see Philips, M. (1994), Between Universalism and skepticism: Ethics as social artifact. Oxford: Oxford University Press. 


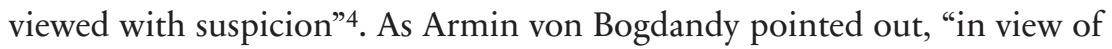
the political, ideological, and cultural fragmentation of global society, every claim to be writing from a global or universal point of view strikes us as potentially hegemonic and guilty of hubris"s. To avoid succumbing to the "apologetic temptation" of using functional arguments to justify institutions $^{6}$ or to the utopian appeal for abstract and general norms, the authors used the broad notions of representation, transparency, deliberation, and participation found in the Treaty on the European Union in order to tackle the legitimacy and democratic deficit of international adjudicative bodies and "chart a path between utopia and apology"

Democracy, one of the three building blocks of the public law theory of international adjudication (hereafter referred to as the "public law theory"), alongside multifunctionality and international public authority, is one of the most controversial topics discussed in the book. Unlike decisions from international courts and tribunals exercising public authority ("ICTs"), judicial decisions from domestic courts have a clear democratic dimension as they are rendered "in the name of the people". The public law theory came in a particular context: the eloquent growth of international adjudication in the last two decades, ${ }^{8}$ and the fact that ICTs now perform numerous functions beyond the settlement of disputes in individual cases, such as "the stabilization of normative expectations", "law-making" and "the control and legitimation of public authority" .

This context and the shifting of the source of legitimacy from domestic courts to ICTs have far-reaching ramifications that could recall the questions raised by independent and semi-independent regulatory agencies ("IRAs"). Regulatory agencies appeared in the United States at the end of the nineteenth century in order to regulate rail transport (through the Interstate Commerce Commission) and then to tackle all the subjects that are technically, legally, or politically complex or sensitive. Later, with the development of interventionist states in the 1980s, they started proliferat-

4 Von Bogdandy, A. (2013), "The Democratic Legitimacy of International Courts: A Conceptual Framework", Theoretical Inquiries in Law 14(2), 361-379, 363, available at https:/www7.tau.ac.il/ojs/index.php/til/article/view/138, accessed 11 February 2020.

5 Bogdandy and Venzke, supra note 2, 26.

6 Ibid., 6.

7 Ibid., 151.

8 "Since 2002, international courts have rendered more judicial decisions every single year than was the case from time immemorial up to 1989", see Ibid., 1.

9 Ibid., 8. 
ing in Europe as the need for "political credibility in an increasingly interdependent world" 10 became clear. Since then, democratic institutions have progressively delegated public authority to these agencies that claimed to produce faster and expertise-oriented decisions and quickly gained autonomy.

If there are practical reasons to justify these trends in a purely functional manner - i.e. the specific needs of regulation or the rising international challenges - such a legitimization would remain unsatisfactory. For the purpose of this contribution, the paper will not discuss the current developments involving all the NMIs but investigate, based on the public law theory of Armin von Bogdandy and Ingo Venzke (hereafter referred to as "the authors"), some of the most acute legitimacy problems that impact both contemporary international adjudication and domestic regulation. Although NMIs take various institutional forms, including ICTs, supranational and international organizations, IRAs, specialized constitutional courts, and central banks, this paper will mostly focus on ICTs and IRAs. It will study the solutions advanced for legitimising ICTs and the prospect to respond to the democratic deficit by some form of input or procedural legitimacy. Two concepts will be mainly considered in this study: the concept of "domestic analogy" and the concept of "delegation", as public authority is being transferred from national democratic institutions to NMIs.

While the public law theory can be conceived as a specific legitimation theory for the specific context of international adjudication, the paper aims at (i) contextualizing the public law theory to understand how domestic analogy is used for legitimizing ICTs, (ii) mapping the public law theory to understand how it articulates with other proposals that developed in the last decades, (iii) and testing the public law theory for the legitimacy concerns of regulatory agencies. A reflection on the democratic legitimacy of NMIs seems indeed very timely as populism is spreading across the world, and non-electoral legitimacy is under pressure.

\section{Domestic Analogy and the Legitimacy of International Adjudicative Bodies}

The public law theory found in domestic law the legal tools to provide legitimacy to international courts and tribunals exercising public authority, hence trying to resolve one of the most controversial challenges in interna-

10 Majone, supra note 1, 11. 
tional law in a manner that could be described as either ambitious or utopian (A). The main obstacle for implementing a public law theory and a viable democratic framework in an international setting lies in the lack of demos at the global level (B).

\section{A. Domestic Analogy and the International Order}

From Analogy to Utopia?

Along with several proposals formulated since the creation of the League of Nations, the public law theory aims at transferring domestic legal and political principles to the international realm. This reasoning is based on a domestic analogy. A domestic analogy means that the principles sustaining order within national states can reproduce order at the international level based on the presumption that national and international phenomena share the same conditions of order. ${ }^{11}$ The domestic analogy is problematic when considered not only as a potentially emulating experience but as a universal ideal to strive for in the long term. Indeed, "[the] conditions of an orderly social life, on this view, are the same among states as they are within them: they require that the institutions of domestic society be reproduced on a universal scale"12, an assumption that is highly debatable.

The quest for world order and unity at large can be criticized for its utopian nature. In an article on "The Mystery of Global Governance", David Kennedy analyzed a contradiction between the "purposive bias [...] against the concept of disorder" and the fact that disorder is a reality of any social life. ${ }^{13}$ More specifically, criticism comes from those who regard international law as a system of law sui generis - especially authors from the late nineteenth and the early twentieth century - and International Relations ("IR") scholars who conceive IR as "dependent on, but separated from Politics" 14 . There are other grounds for being skeptical in this respect: the

11 Suganami, H. (1966), The Domestic Analogy and World Order Proposals. Cambridge: Cambridge University Press, 1.

12 Bull, H. (1966), "Society and anarchy in international relations" In: H. Butterfield and M. Wight (eds), Diplomatic investigations. Oxford: Oxford University Press, $35-60$.

13 Kennedy, D. (2009), “The Mystery of Global Governance” In: J.L. Dunoff and J.P. Trachtman (eds), Ruling the World?. Cambridge: Cambridge University Press, 3768.

14 To see Manning's criticism: Suganami, supra note 11, 10. 
impression that analogy is less scientific than deductive reasoning, the assumption that states need to be considered differently from individuals, and the rejection of legalism or cosmopolitanism. ${ }^{15}$ Analogy has nonetheless been repeatedly used as a tool to conceptualize the international legal order.

In the Leviathan, Thomas Hobbes assumed that the conditions of an orderly social life for individuals differed from conditions of order among states. In a Hobbesian perspective, the invention of political sovereignty puts an end to the anarchy between individuals (or the "state of nature"), which leads to a "war of all against all" ${ }^{16}$. Hobbes drew a parallel with the anarchical international order but he did not consider the feasibility or the necessity of an international social contract. Therefore, it is not clear whether the idea of a global sovereign to solve interstate conflict was "in the very logic of his argument" or if it was instead a lacuna that could either be left unexplored or bring explanations on the reasons why states' anarchy does not lead to a state of war. ${ }^{17}$ Hedley Bull, a critic of the domestic analogy who engaged with the lacuna, claimed that, according to Hobbes, the anarchy between individuals who are threatening each other in the state of nature would be fundamentally different from the risks incurred by states. As sovereigns would then belong to the state of nature, the "Hobbesian view" is still considered by numerous political scientists as the realistic position, ${ }^{18}$ and it is usually opposed to the liberal approach of IR, associated with Immanuel Kant.

Unlike the English philosopher, Kant clearly drew an analogy between individuals and states, stating in the Metaphysics of Morals that "states, like lawless savages, exist in a condition devoid of right" in the international state of nature. ${ }^{19}$ A few years later, he pushed the analogy further: "[no]

15 Ibid., 16.

16 Hobbes, T. (1996) [1651], Leviathan. Cambridge: Cambridge University Press, Chapter 13.

17 Grewal, D.S. (2016), “The Domestic Analogy Revisited: Hobbes on International Order", Yale Law Journal 125(3), 618-680, 628-630, available at https://www.yalela wjournal.org/essay/the-domestic-analogy-revisited-hobbes-on-international-order, accessed 11 February 2020.

18 Morgenthau, H. (2005), Politics Among Nations. New York: McGraw-Hill Education; for a critique of the confusion between the Hobbesian and the realistic view and a reflection on Hobbes as 'a theorist of international peace, see Grewal, supra note 17.

19 Kant, I. (1797), Die Metaphysik der Sitten ("Metaphysics of Morals"), as translated by Nisbet, H.B. (1991), Kant's political writings ( $2^{\text {nd }}$ ed.). Cambridge: Cambridge University Press, 131-175, 165. 
where does human nature appear less admirable than in the relationships which exist between peoples" ${ }^{20}$. Progressively, after World War I, this Kantian image of sovereign states forming legal subjects within an international community, just like individuals in the domestic order, started influencing international lawyers and legal theorists. ${ }^{21}$

\section{The Legitimacy of International Institutions}

At the heart of the concept of domestic analogy as it is used today, lies the question of the international government, or to quote Kant, of a "federation of nations" - Völkerbund. The relevance of domestic analogy is called into question by the fact that, in the domestic sphere, the existence of the body politic universally depends on the "harmonious action of the three factors, legislation, adjudication and execution", whereas no such equivalent exists at the international level. ${ }^{22}$ Following the concept of separation (or "distribution") of powers commonly credited to Montesquieu, "[these] three powers should naturally form a state of repose or inaction. [...] They are forced to move but still in concert" 23 . As there is no legislative power at the world stage, it seems impossible to reproduce the check and balance system with one or two of the three instruments of the concert missing on the international stage, resulting in a major problem of legitimacy. ${ }^{24}$ In this regard, the case law of the Court of Justice of the European Union ("CJEU") is quite specific as it performs as a "true third branch", in harmony with "a European legislator and a European executive which can respond to the decisions of the court" 25 . Unlike international courts, the CJEU is functioning within a centralized political framework that displays a unique example of dual legitimation (the European Parliament representing the EU citizens on the one hand; the Council of the EU and the European Council representing EU Member States on the other hand). Therefore, the authors chose not to include it in their study.

20 Ibid., 91.

21 Koskenniemi, M. (2005), Global Legal Pluralism: Multiple Regimes and Multiple Modes of Thought. Cambridge: Cambridge University Press, 22.

22 Lorimer, J. (1884), The institutes of the law of nations (2 vols). Edinburgh: William Blackwood and Sons.

23 Montesquieu, C. (1758), De l'Esprit des Lois, Livre XI, Chapitre VI.

24 See the contribution of Aida Torres for a discussion on the different "democratic pedigree" of international courts and tribunals.

25 Bogdandy and Venzke, supra note 2, 25. 
As for the functioning of other international courts, Hidemi Suganami found three grounds for criticism against the principle of compulsory jurisdiction into international law that show how flawed the design of international institutions may be. ${ }^{26}$ First, while law can "give an answer to every dispute, not all disputes can be resolved thereby" since the contestants of an international legal dispute may never respect a legal settlement (as in a hypothetical case where the US and the USSR would be part of an international legal dispute just to "test their respective strengths"). Second, a poor system of sanctions of international judicial decisions makes compulsory jurisdiction unlikely to fill its role. Suganami mentions the "excessive confidence in the capacity of law" of Lauterpacht's argument according to which "the absence of centralized sanctions would reduce, but not substantially impair, the function of the judiciary endowed with compulsory jurisdiction". Third, ineffective compulsory jurisdiction is worse than the absence of compulsory jurisdiction as it explicitly shows the bad faith of the party that fails to comply with the decision and potentially aggravates political conflicts.

Domestic analogy precisely served as the "background framing" of global governance proposals that are meant to correct the deficiencies in the system of sovereign states. ${ }^{27}$ As state consent and procedural fairness cannot suffice to ground the legitimacy of ICTs and other global institutions, theories on democratic legitimacy, global accountability and constitutionalism are indeed among the topics discussed by legal scholars to try solving their legitimacy deficit in the absence of a demos.

\section{B. Democratic Legitimacy and the Demos}

The approach of the authors aims at getting closer to the reality of judicial law-making by challenging the "private-law inspired foundation of international law" 28 . Their reason to do so is that the state-consent approach does not reflect the dynamic of the international judiciary, as the example of the World Trade Organization's ("WTO") institutional development clearly demonstrates. ${ }^{29}$ The authors' theory is not only descriptive but also constructive: they present their work as "a principled reconstruction of the law

26 Suganami, supra note $11,171-177$.

27 Grewal, supra note 17, 628.

28 Bogdandy and Venzke, supra note 2, 3.

29 See ibid., 85 for an extensive description of this example. 
of international courts $[\ldots]$ informed by political theory and practical philosophy" 30 .

\section{A European Agenda}

In the section on the Agenda and Objectives, the authors acknowledged their particular vantage point and the fact that their work was shaped in Amsterdam and Heidelberg, from 2008 to 2013 by two Europeans who are influenced by "a specific tradition of thinking and the context of contemporary debates on the democratic legitimacy of international institutions" 31 . None of these disclosed facts is a reason to blame the authors for an alleged Eurocentrism. However, behind their technocratic ambition to use European provisions may lie a utopian European project.

The goal of the authors is to use the provisions on the democratic principles from the TEU to frame the democratic legitimation of international courts: "in Articles 9-12 TEU we find a framing of democracy for institutions beyond the state that is neither utopian nor apologetic, but plausible and viable" 32 . The public law theory thus becomes a means to universalize principles proclaimed in the TEU. Yet, even if we put aside the internal problems of the EU, its democratic deficit and its growing discontent, ${ }^{33}$ what gives legitimacy to "fair weather institutions" 34 may not be credibly replicated elsewhere. Such an agenda can nevertheless be understood in the light of the European trend of German public law.

30 Ibid., 22.

31 Ibid., 26.

32 Ibid., 136.

33 As Armin von Bogdandy put it himself, it is "not a democratic showcase". Bogdandy, supra note 4, 362 .

34 Expression borrowed from the French sociologist Hassner, P. (1995), La violence et la paix, Paris: Esprit, 375-376. 
The promotion of the ius publicum europaeum

While authors from the nineteenth century tried to expose German public law as "a set of rules establishing and regulating the workings of the institutions of government" 35 , the endeavour now seems to aim at promoting these rules and principles across Europe. ${ }^{36}$ The Max Planck Institute for Comparative Public Law and International Law may well be today's epicenter of this movement, as it is hosting the ius publicum europaeum project. Put in its national and historical context, the ius publicum europaeum project can be related to the German trend of framing constitutional authority at a supranational level to alleviate the concerns raised by the lack of unity of international law. ${ }^{37}$ The fact that different attempts to legitimize international jurisdictions emerged in Germany is by no means incidental. Indeed, the belle époque of the ius publicum europaeum ${ }^{38}$ is a result from the evolution of German public law. The ius publicum europaeum project aims at redefining national concepts of the EU member states in light of a new reality: the European legal order. Unlike the French tradition of public law, which is state-centered and focused on the public service or the puissance publique, the project presupposes that it is no longer relevant to consider states as the only purpose of public law theories. ${ }^{39}$ The European Union could ideally serve such a purpose as it is a

35 Loughlin, M. (2013), “The Nature of Public Law” In: C. Mac Amhlaigh, C. Michelon and N. Walker (eds), After Public Law. Oxford: Oxford University Press, 1124.

36 Ibid.

37 Walker, N. (2009), "Multilevel Constitutionalism: Looking beyond the German debate", LSE 'Europe in Question' Discussion Paper Series (LEQS) 8, 1-30.

38 Jouanjan, O. (2014), "Remarques sur l'Histoire du droit public en Allemagne (1800-1914) : pourquoi lire Michael Stolleis en France?", Jus Politicum 12, 1-6, available at http://juspoliticum.com/article/Remarques-sur-l-Histoire-du-droit-pub lic-en-Allemagne-1800-1914-pourquoi-lire-Michael-Stolleis-en-France-886.html, accessed 15 January 2020: "Seule une connaissance approfondie de la doctrine allemande du XIXe siècle permet de comprendre la «belle époque» du droit public européen, et spécialement la construction de la grande doctrine française, à travers cet affrontement politiquement conditionné, mais scientifiquement productif qui a fait naître les auvres majeures du droit public français. Le droit public allemand de la fin du XIXe siècle est un peu "l'envers de l'histoire contemporaine» du droit public français."

39 Xifaras, M. (2012), "Après les Théories Générales de l'État : le Droit Global?", Jus Politicum 8, 1-57, available at http://juspoliticum.com/article/Apres-les-Theories-G enerales-de-l-Etat-le-Droit-Global-622.html, accessed 11 February 2020. 
supranational democracy that displays a dual legitimation (from states and from the European citizens), and reflects "une idée d'oeuvre commune" 40.

\section{An unachievable common project?}

The ius publicum europaeum project and the public law theory share a similar rationale and are both strengthening the principles at the core of the European Union. This might be problematic considering the political theory debates on the existence of a "European identity" 41 . Indeed, conflict and consensus are necessary elements of democracy, as well as a sense of collective self-identification and a common project. The sense of belonging to a common project is usually shaped by a confrontation with other existing projects. Like identity, democracy develops in a symbolic framework of emotions and rejections. It is often shaped by sacrifices, wars and hatred. The fact that these common experiences do not exist at the international level partly explains why democracy has never been successfully practiced at a supranational level so far. The Habermassian project to frame a European constitutional patriotism may be too "dry and abstract" to resolve the European identity issues and the lack of a European homeland. ${ }^{42}$ To face the current heterogeneity at the European level, the ius publicum europaeum project seeks to offer concrete solutions, such as educating lawyers to provide them a better understanding of European national legal systems and better promote mutual acquaintance between European citizens, a way to strengthen the European identity and improve the ius publicum europaeum science, which is still in embryonic state.

40 Azoulai, L. (2015), "Solitude, désœuvrement et conscience critique", Politique européenne 50(4), 82-98.

41 On this issue of European identity, see for example Keulman, K. and Koós, K.A. (2014), European Identity: Its Feasibility and Desirability. Maryland: Lexington Books.

42 Meny, Y. (2011), "Can Europe be Democratic? Is it Feasible? It is Necessary? Is the Present Situation Sustainable?”, Fordham International Law Journal 34(5), 12871303, 1302, available at http://ir.lawnet.fordham.edu/ilj/vol34/iss5/6, accessed 11 February 2020. 
Several competing proposals aimed at tackling the deficit of legitimacy of international institutions and the alleged need for unity and order. We have come to a point where it is rather a "disorder of orders" 43 that comes out of these unifying attempts.

\section{Proposals to Legitimize International Adjudicative Bodies - A Disorder of Orders?}

As a result of the fragmentation of the international order, which is itself caused by globalization and the emergence of new institutions and particular regimes, international lawyers try to find appropriate responses using the language they know and "the gift of vocabulary that gives sense to plurality" 44 . The public law theory provides to this plurality of institutions and rationalities an analytical framework and fits into the ambitious proposals that have emerged in the past two decades to seek solutions to the legitimatory concerns raised by the development of international adjudication. The main proposals forming the backbone of this general framework are global constitutionalism (A) and multilayered governance approaches (B).

\section{A. Constitutionalist approaches}

The issue of the applicability of constitutionalism to the international order covers a broad range of positions that differ from one author to another. Armin von Bogdandy and Ingo Venzke share with constitutionalist authors "the conviction that the stock of principles of the democratic constitutional state is important to international law" 45 . However, they differ regarding the "step too far" that constitutionalists cross when they attribute constitutional functions to existing institutions indistinctly. Some organizations fulfil functions that can be interpreted as constitutional, as in the WTO legal order. Yet, the treaties founding such organizations only

43 Walker, N. (2008), "Beyond boundary disputes and basic grids: Mapping the global disorder of normative orders", International Journal of Constitutional Law 6(3-4), 373-396.

44 Koskenniemi, supra note 21, 4.

45 Bogdandy and Venzke, supra note 2, 123. 
provide "micro-constitutionalizations" 46 at best. ${ }^{47}$ Other approaches are even more holistic and utopian: among them is the project to conceive the United Nations Charter as the constitution of the international community, ${ }^{48}$ which may ultimately reinforce the institution that reflected the distribution of power after World War II, ${ }^{49}$ or the Habermasian foundational constitutionalism conceptualized in the European framework.

Two constitutionalist "dangers" are mentioned by the authors of the public law theory. First, the fact that the constitutionalist argument not only "expands" the concept but "dilutes" it, giving room for any interpretation of international law from any international court to have a constitutional function. ${ }^{50}$ Anne Peters anticipated this reproach: "if all (international) law is somehow constitutionalized, then nothing is constitutional" 51 . The constitutionalist agenda seems less about describing the reality than conceiving the international legal order in a new light, through a comprehensive approach with an assumed moral and ideological bias. Its relevance lies in the "symbolic-aesthetical dimension inherent in national constitutional law" 52 . Far from being a mere set of norms, a constitution is also the mythological result of conflicts that have had a historical and foundational meaning, as in the French and American traditions. In one word, a Constitution is "owned" by a people. ${ }^{53}$ Knowing the intricacies of

46 However subtle, this term is not paradoxical: it presupposes a rejection of the "myth" of the unity of constitution and the refusal to consider that the concept of "constitution" necessary relates to state constitutions. See Peters, A. (2009), "The Merits of Global Constitutionalism”, Indiana Journal of Global Legal Studies 16(2), 397-411, 402.

47 Peters, A. et al. (2011), "The Constitutionalisation of international trade law" In: T. Cottier and P. Delimatsis (eds), The Prospects of International Trade Regulation. From Fragmentation to Coherence. Cambridge: Cambridge University Press, 69-102. For a more ambitious approach of WTO's constitutionalism, see Petersmann, E.U. (1992), "National Constitutions, Foreign Trade and European Community Law”, European Journal of International Law 3(1), 1-35.

48 Fassbender, B. (1998), "The United Nations Charter as Constitution of the International Community", Columbia Journal of Transnational Law 36(3), 529-619.

49 Krisch, N. (2009), "Global Administrative Law and the Constitutional Ambition", LSE Legal Studies Working Paper (10), 1-22, available at https://papers.ssrn.com/sol 3/papers.cfm?abstract_id=1344788, accessed 11 February 2020.

50 Bogdandy and Venzke, supra note 2, 131.

51 Peters, supra note 46, 403.

52 Peters, A. (2006), "Compensatory Constitutionalism: The Function and Potential of Fundamental International Norms and Structures”, Leiden Journal of International Law 19(3), 579-610, 582.

53 Peters, supra note 46, 400. 
the constitutionalist project, Anne Peters based her theory on a radical project of refoundation of international law. She ousted the principle of sovereignty from its cardinal position to replace it with the principle of humanism. ${ }^{54}$ She also supplanted the principle of state consent with majoritarian decision-making so that "world citizens" can be viewed as the ultimate reference points of democracy, not states. Even if the public law theory does not rest on the same assumptions, it remains confronted with the same problem, albeit to a lesser extent. Like a constitution, public law is also embodying a political community, which is itself rooted in a democratic framework.

\section{B. Multilayered governance approaches}

\section{The global administrative law project}

Despite the overlaps, the public law theory is more modest and less utopian than the constitutionalist project. A comparison with global governance approaches seems more appropriate as they claim to be different from top-down constitutionalist approaches. The very existence of global administrative law shows that international courts' activities can no longer be seen as sporadic dispute resolution as they must be conceived as administration. ${ }^{55}$ Instead of using a foundational source of legitimation similar to constitutionalists', global administrative law ("GAL") advocates are inspired by administrative law; the field of law that governs the administrative agencies of government. GAL aims at making global administrative bodies accountable for the tasks that states used to perform themselves, such as the administration of public property. However, unlike similar approaches, GAL does not necessarily reuse the tools of domestic administrative law for institutions of global governance. Administrative law is less used by analogy than as a source of inspiration and contrast. ${ }^{56}$ Indeed, it is more of a sociological project, whose goal is to be closer to the reality of the global world, and of practical use in the global governance space.

54 Peters, A. (2009), "Humanity as the A and $\Omega$ of sovereignty", European Journal of International Law 20(3), 513-544.

55 See Bogdandy and Venzke, supra note 2, 82, and Kingsbury, B., Krisch, N. and Stewart, R.B. (2005), "The emergence of global administrative law", Law and Contemporary Problems 68(3-4), 15-61.

56 Domestic administrative law is used "as a background rather than as the basis for prescription”. See Krisch, supra note 49, 13. 


\section{The public law theory and global projects}

The practical goals of the public law theory often converge with the constitutionalist literature and global governance approaches: the procedural standards about the publication of decisions and transparency, the need for substantiated rulings, and the possibility to appeal. However, it has been shown that the limited ambitions of global governance are not as limited and practical as portrayed. ${ }^{57}$ The GAL project and the public law theory not only have common features, they also share philosophical underpinnings, publicness being the common basis for both approaches. A rule produced by a global actor is related to GAL only if it complies with the inherent qualities of public law. The criteria of these inherent qualities of public law are the general principles of public law: "legality", "rationality", "proportionality", "the rule of law" and "human rights". Here lies a bridge between constitutional law approaches and the authors' theory.

A brief cross-analysis of the differences and similarities between the proposals leads us to wonder if the authors are providing an alternative to the existing projects or if it is rather a synthesis aiming at fixing shortcomings in both theories. On the one hand, these projects look similar and complementary as they are all using the public law language as a strategy for legitimization. On the other hand, the public law theory might also combine issues raised by the competing proposals. In sum, it appears increasingly difficult to "disentangle the administrative from the constitutional" 58 as questions of legitimacy persist.

The article "Developing the Publicness of Public International Law" helps understanding why the authors felt the need to fill the lack of legitimacy through a public law approach to international law in their book. ${ }^{59}$ Analyzing the discourse on global governance, Armin von Bogdandy explicitly found it "deficient from a public law perspective" 60 . In his opinion, a public authority is legitimate only if constituted and limited by pub-

57 See "Le constitutionnalisme processuel, un projet modeste... revu à la hausse" in Martineau, A.-C. (2016), Le débat sur la fragmentation du droit international. Une analyse critique. Bruxelles: Bruylant, 117-172; Kingsbury, B. (2009), "The concept of 'law' in global administrative law”, European Journal of International Law 20(1), 23-57; and Krisch, supra note 49.

58 Ibid.,16.

59 Von Bogdandy, A., Dann, P. and Goldmann, M. (2008), "Developing the Publicness of public international law: Towards a legal framework for global governance activities", German Law Journal 9(11), 1375-1400, available at http://papers.ssrn.co m/sol3/papers.cfm?abstract_id=1348809, accessed 11 February 2020.

Ibid., 2. 
lic law. The problem the authors had to face is that the concept of public law does not seem to fit the categories of global governance, especially so when the measures are non-coercive, informal or not related to the public sphere. Global governance covers topics such as health, human rights, environment, trade, education, and finance. The concept can be used for the impact of the Pisa rankings made by the Organisation for Economic Cooperation and Development on educational policies as well as for the role the credit rating agencies played in the American subprime crisis of 20072008. Therefore, it seems impossible to understand the emergence of global governance fully, let alone find its source of legitimacy: "[we] do not know how power is put together on the global stage let alone how its exercise might be rendered just or effective" 61 .

Therefore, unlike GAL advocates, the authors decided to narrow the focus on international courts that exercise authoritative acts of public authority. However, the different language used shows that the authors are thinking within a public law framework as if using public law was a necessary condition for legitimizing any act of authority: "[we] suggest the shift towards the exercise of international public authority in order to better identify those international activities that determine other legal subjects, curtail their freedom in a way that requires legitimacy and therefore a public law framework" 62 . The idea that publicness and a public law framework are required to ensure legitimacy is at the core of the author's demonstration. In legal and political terms, using a public law framework is less ambiguous and more familiar than the global governance vocabulary. ${ }^{63}$ However, the fact that GAL thinkers prefer using another paradigm instead of more traditional concepts such as "public law" or "democracy" appears more in line with the diffused nature and object of global governance. Such a concept also gives ground to the legitimization of domestic regulatory agencies.

61 Kennedy, supra note 13, 828.

62 Bogdandy, Dann and Goldmann, supra note 59, 1381 (emphasis added).

63 Ambiguity is inherent in Global Administrative Law, see Finkelstein, L.S. (1995), "What Is Global Governance?", Global Governance 1(3), 367-372, available at http:/ /www.jstor.org/stable/27800120?origin=JSTOR-pdf, accessed 11 February 2020. 


\section{The Democratic Legitimacy of Independent Regulatory Agencies}

To conceptualize their public law theory, the authors used Articles 9-12 of the Treaty on the European Union, considering that these articles could help theorize the democratic credentials of ICTs. The principles that underlie these articles are about citizenship, representation, participation and transparency. They are all very similar to the principles put forward by a French historian and sociologist, Pierre Rosanvallon, to investigate the legitimacy of regulatory agencies. ${ }^{64}$ While these institutions feature a peculiar institutional design as non-majoritarian institutions that increasingly take political decisions (A), they raise legitimacy concerns similar to the challenges faced by international adjudication (B).

\section{A. The institutional design of regulatory agencies}

\section{Non-identified political objects}

Whether they are specifically called "Non-departmental Public Bodies" in the UK, "Independent Regulatory Agencies" in the US, or "Autorités administratives indépendantes", as in France, they are characterized by a hybrid model: they are executive authorities that combine legislative and adjudicative functions. Initially created in the US at the end of the nineteenth century to depoliticize key sectors of the economy (such as the US railway), their supposed benefits made them popular worldwide and democratic institutions progressively "lost terrain vis-à-vis non-majoritarian institutions, due to resources restrictions and policy complexity" ${ }^{65}$. Yet, their conceptualization as specific political forms has proved challenging, even in France where a strong tradition of codification exists. No effort has been made to codify the law of independent authorities or reflect on them as if preserving a pragmatic approach was preferred over their conceptualization. ${ }^{66}$ The organic law $n^{\circ} 2017-54$ and the ordinary law $n^{\circ} 2017-55$ enumerated a list

64 Rosanvallon, P. (2010), La légitimité démocratique. Paris: Point; see P. Rosanvallon translated by Goldhammer, A. (2011), Democratic legitimacy: Impartiality, reflexivity, proximity. Paris: Points.

65 Biela, J. (2014), "What Deficit? Legitimacy and Accountability of Regulatory Agencies”, Working Paper prepared for the $42^{\text {nd }}$ ECPR Joint Sessions, Salamanca, 1-22, available at https://ecpr.eu/Filestore/PaperProposal/c294ff37-abb7-4aff-8583868a1fa3b227.pdf, accessed 11 February 2020.

66 Rosanvallon, supra note 64, 160. 
of 26 agencies (19 autorités administratives indépendantes and 7 autorités publiques indépendantes, the latter having legal personality) and stated that the legislator was the only body competent to create these two types of agencies. Interestingly, the law provides no definition of what constitutes one of these agencies as a mere enumeration was preferred. Being established ex nibilo or recognized ex post facto, these agencies propagated with no vision and coherent agenda. It is mainly the output legitimacy of IRAs, i.e. their ability to effectively respond to their policy outcomes, that accounts for their development across Europe.

\section{The rise of the unelected}

While legitimacy in a modern democracy should be established via elections, according to the principles of representative democracy and the sovereignty of the people, the fact that increasing important policy-making powers are transferred from the administration and the democratic institutions (government and parliament) to non-elected agencies constitutes an acute challenge to democratic legitimacy. These agencies that form the "regulatory state" are part of the United States model of democracy and illustrate its pragmatic way to correct the deficiencies of the market. Their decision-making process articulates within the checks and balances system. ${ }^{67}$ Instead, in the European tradition - setting aside the United Kingdom and Scandinavian countries - it was more common to assign new ministerial powers and reorganize government departments rather than contravening the idea of state's unity representing the public interest with agencies detached from the state and exercising public authority.

\section{Regulatory agencies in Europe}

Unlike in the United States, IRAs in EU Member States were mostly imposed by EU constraints, especially regarding the liberalization of telecom, banking and postal industries. To enforce transparent competition and prevent state-owned historical operators from benefiting from their monopolistic position, independent regulatory agencies became necessary

67 Frison-Roche, M.-A. (2011), "Les autorités administratives indépendantes: distorsion ou réforme de l'État?" In: J.-P. Betbèze and B. Coeuré (eds), Quelles réformes pour sauver l'État?. Paris: Presses Universitaires de France, 125-130, 125-126. 
tools in countries that decided, as in the case of France, not to immediately privatize their public operators, for reasons related to public services. ${ }^{68}$ As they are contrary to the unity of the state and alter the way the separation of powers is perceived in the continental tradition, they are accepted but often seen as dismantling of the state (démembrement de l'État). As a result, politicians often interfere in the decisions of national and EU regulators, especially when they acquired "habits $[\ldots]$ of pervasive state interventionism", making them less independent "de facto and generally also de jure" than their American counterparts. ${ }^{69}$

\section{Regulatory agencies in the US}

In the United States, all the American federal agencies, even the ones which are not independent, are commonly described as a "fourth branch of government"70 fully embedded in the check and balances system, and allowing to restrict the political powers and "impede the tyranny of the majority" "1. The 1946 Administrative Procedure Act stated how agencies could establish regulations under the control of federal courts and played a role as the main source of the US administrative law. Thus, the powers of executive agencies (government departments, Federal Bureau of Investigations, Central Intelligence Agency, etc.) are subject to the political will of the US President, while those of independent agencies (Federal Communication Commission, Securities Exchange Commission, Federal Reserve Board, etc.) are independent of his or her political ideas and have statutory guarantees of independence. ${ }^{72}$ But it is only due to a transatlantic misunderstanding that agencies are seen strictly independent from the political power. As Posner stated in 1974, "the agency's head is answerable both to the legislative and (if he desires promotion or reappointment) to the execu-

68 Ibid., 127.

69 Majone, supra note 1, 11.

70 Brownlow, L. et al. (1937), Report of the Committee, with Studies of Administrative Management in the Federal Government. Washington: U.S. Government. Print, 3839.

71 Maggetti, M. (2010), "Legitimacy and Accountability of Independent Regulatory Agencies: A Critical Review", Living Reviews in Democracy, 1-9, 2-3, available at https:/ethz.ch/content/dam/ethz/special-interest/gess/cis/cis-dam/CIS_DAM_2015 /WorkingPapers/Living_Reviews_Democracy/Maggetti.pdf, accessed 11 February 2020.

72 Zoller, E. (2004), "Les agences fédérales américaines, la régulation et la démocratie", Revue française de droit administratif (4), 751-771. 
tive branches"73. Moreover, agencies are independent only when needed for reasons related to their functions (i.e. following the principle of independence of the judiciary power, an agency can only have a sanctioning power if its adjudicative power is insulated to an organ independent from the agency) or depending on the sector concerned, once the political authorities decided that this sector should be independent of the influence of political parties. ${ }^{74}$ In sum, American agencies have variable degrees of independence, but they have more independence and a more refined structure of accountability than at the EU level. ${ }^{75}$

\section{B. Output and Input Legitimacy of Regulatory Agencies}

\section{The output legitimacy of regulatory agencies}

NMIs in general, and IRAs in particular, are usually established for two main reasons. First, as they do not rely on representative bodies but on neutral experts, they can implement policies in an efficient and effective way, their independence allowing them to be insulated from the arena of day-to-day politics ${ }^{76}$. The delegation of power to experts allows agencies to produce more effective results and lower decision-making costs: since legislators and government executives save precious time and resources avoiding to "[refine] legislation", they get more policy leeway to introduce new legislation or carry out a broader political agenda. ${ }^{77}$ Second, the development of NMIs comes from the opportunistic "blame-avoidance hypothesis" and the interest to have responsibility for policy-failures shift from legislators to other decision-makers. NMIs may be convenient tools to avoid the political cost of unpopular decisions and release the regulation of key sectors from the short time horizon of electoral politics and the expectation of alternation, which cause a lack of credible commitments. ${ }^{78}$ Their functional advantages come from their procedural features.

73 Posner, R.A. (1974), “Theories of Economic Regulation”, The Bell Journal of Economics and Management Science 5(2), 335-358, 338.

74 Zoller, supra note 72.

75 Such generalization can, of course, be nuanced, considering for instance how the ECB enjoy an exceptionally high degree of independence, for reasons related to the reputation of the Euro and the need to fight inflation.

76 Majone, supra note 1, 21.

77 Ibid., 3.

78 Ibid., 4. 


\section{The delegation of public authority}

Delegation is defined by Mark Thatcher as "an authoritative decision, formalised as a matter of public law, that (a) transfers policy making authority away from established, representative organs (those that are directly elected, or are managed directly by elected politicians), to (b) a nonmajoritarian institution, whether public or private"79. As it has become one of the primary modalities of public policy, delegation is problematic when the objectives of the agents differ from their principals' The non-delegation doctrine, theorized by John Locke in his Second Treatise on Civil Government, implied that policy-making powers cannot be delegated as legitimacy cannot be transferred: "The legislature cannot transfer the power of making laws to any other hands". However, this theory has been "repealed by long-established constitutional practice" 80 and the influence of American "contractual political theory" ${ }^{2}$. As far as the paper is concerned, the logic of delegation is raising legitimacy issues due to the gap between the functions and the impact of IRAs and ICTs and their initial delegations. If "international tribunals [were] practical devices for helping states to resolve limited disputes when the states are otherwise inclined to settle them," as evoked by Richard Posner in a chapter on "adjudication in anarchy" 82 , there would be no real issue of legitimacy. But ICTs have become problematic agents of states, just like regulatory agencies.

\section{The independence of non-majoritarian institutions}

NMIs' independence from the "politico-administrative state hierarchy" constitutes the main part of their input legitimacy and the source of their output legitimacy. It allows them to apply public authority in a distinct form of political power, which is called "regulatory power" ${ }^{83}$. IRAs have a rationale which is often "exogenous" to states. Regulatory matters, especially in finance, are usually sensitive, complex and have international consequences, hence the need for discretion and distance from governments.

79 Thatcher, M. and Stone Sweet, A. (2002), "Theory and Practice of Delegation to Non-Majoritarian Institutions", West European Politics 25(1), 1-22, 3.

80 Majone, supra note 1, 7-8.

81 Ibid.

82 Posner, R.A. (2009), The Perils of Global Legalism. Chicago: University of Chicago Press, 129.

83 Maggetti, supra note 71. 
Moreover, markets that need to be regulated can be "more powerful than states", as a result of their global scale and of the mobility of economic actors. ${ }^{84}$ This is particularly the case for financial regulation matters. The need to have non-elected bodies implement policies has also been clearly established for a particular kind of NMIs, central banks. The reason why numerous financial experts, politicians and economists advocate for the independence of central banks is that they should be free from political interference to be able to keep inflation low and perform their functions. In other words, as is the case for IRAs, central banks obey a legitimization narrative that stresses the need to limit input legitimacy - by limiting the involvement of democratic institutions and the accountability of central banks officials - for achieving output legitimacy. ${ }^{85}$ Apart from their independence, the efficiency of NMIs results from their demanding procedural accountability. Like ICTs, IRAs have a specific democratic pedigree as they are required to use their decision-making powers in a more transparent, open and lawful way than bureaucrats and elected politicians. ${ }^{86}$

Therefore, there seems to be a negative correlation between input and output legitimacy: democratic legitimacy (and elections in particular) may form an obstacle to deliver better outcomes. ${ }^{87}$ However, instead of sacrificing institutions that could be useful and "effective" - a concept all the more delicate as effectiveness may contradict the desires of the citizens - to government policy, substitutes to electoral legitimacy may be found. As summarized by Scholten, “'Input legitimacy' does not equal 'elections'; rather, democratic input legitimacy = authorization + safeguards + accountability" 88 . Therefore, she investigated in line with Pierre Rosanvallon on how democratic legitimacy could be implemented out of an electoral framework.

84 Frison-Roche, supra note 67, 127.

85 Majone, G. (1997), "Independent Agencies and the Delegation Problem: Theoretical and Normative Dimensions” In: B. Steunenberg and F. van Vught (eds), Political Institutions and Public Policy: Perspectives on European Decision Making. Dordrecht: Springer, 139-156.

86 Maggetti, supra note 71, 3.

87 Scholten, M. (2015), "Democratic Input Legitimacy of IRAs: Proposing an Assessment Framework", Utrecht Law Review 11(2), 64-77, 65.

88 Ibid., 77. 


\section{Procedural accountability: the road to input legitimacy}

Instead of doing careful scrutiny of the functioning of different agencies, Pierre Rosanvallon chose to refer to an idéal-type and tried to identify a set of procedural rules that would make these institutions legitimate. Quite similarly to the authors of the public law theory, he questioned the way in which institutions are deemed legitimate. Noting that regulatory agencies enjoy "secondary legitimacy" ("légitimité dérivée") since the law established them, Pierre Rosanvallon considered that this cannot be a unique and satisfactory source of legitimacy as these bodies are non-elected and yet increasingly powerful.

Just as the authors of the public law theory refused to regard functionalist approaches as the only source of legitimation of ICTs, Pierre Rosanvallon pointed out that functional advantages should not be the only source of legitimacy of IRAs. Functionalism can explain the rising power of international courts or regulatory agencies, not justify it. To go beyond a functionalist reasoning, Pierre Rosanvallon based the democratic legitimation of regulatory agencies not only on their independence, but also on impartiality and transparency.

\section{Legitimacy through impartiality and transparency}

The traditional and widely-accepted procedure to choose the representatives is the election. Questioning the existence of representation without elections, he conceptualized representation through impartiality ("la représentation par l'impartialite"). Rosanvallon's inspiring reflections and his references to Hannah Arendt's Lectures on Kant's Political Philosophy give an interesting account on impartiality. Adopting Kant's point of view, according to whom impartiality means "adopting all conceivable points of view," Arendt considered that "active impartiality" was not achieved by detachment but via a "reflective immersion" in the word. ${ }^{89}$ Instead of an electoral understanding of representation, based on the idea that the rule of the majority stands for the will of the whole, representation can consist of seeking out minority perspectives. This analysis of impartiality, which allows to draw a parallel with the democracy-oriented conception of inter- 
national adjudication described by the authors of the public law theory, ${ }^{90}$ gives room to a democratic theory that does not depend on elections.

Concerned about the need for democratic involvement, Pierre Rosanvallon gives much importance to transparency, as the "democratic appropriation" of agencies can only be possible if their composition and their functioning are transparent. Their activity must be subject to public reporting and lead to public debate; the problems they encounter must be discussed publicly; the parliament should play a constant role in determining their missions, and they must allow citizens to challenge their decisions. In other words, IRAs should be made accountable to both their principals top-down accountability to the political institutions that grants their democratic legitimacy - and their stakeholders - bottom-up accountability to the organized interests and the public opinion at large. ${ }^{91}$ Legitimacy through impartiality, as it is shown, is an endless fight ("une légitimité [...] sans cesse à conquérir"). Indeed, NMIs must make decisions in the public interest, and it is crucial that they interact with the general audience to avoid that their political independence came at the expense of democratic accountability.

While the scope of the competences of IRAs needs to be predefined, agencies should later commit to the policy objectives that are assigned to them "to enforce accountability by results" and strictly and transparently follow the procedures that have been defined..$^{92}$ Otherwise, their independence would lead to arbitrariness instead of being a bulwark against it. The extent to which democratic institutions such as the parliament could interfere in their action is complex and varies depending on the political and legal culture and the degree of expertise that the topic requires (e.g. privacy issues and data protection laws are technical subjects that still need public debates). As for the importance that Pierre Rosanvallon grants to the issue of public involvement, this seems much less feasible when the demos in question is diffused at the international level.

90 See section on "Pathways of Democratic Legitimation" in Bogdandy and Venzke, supra note 2, 161, for the quotation of Hersch Lauterpacht: "impartiality [...] is in the last resort a personal quality of intellect and conscience. [...] It presupposes on [the judges'] part the consciousness of being citizens of the world".

91 Maggetti, supra note 71, 4.

92 Majone, supra note $1,15$. 


\section{Democratic legitimacy beyond the state}

Paraphrasing Robert Dahl, one could wonder if a theory of democratic legitimation is not a mere attempt to "clothe [international courts] in the mantle of democracy simply in order to provide them with greater legitimacy" 93 . The main difference between the conceptions of democratic legitimacy brought by Rosanvallon and the one used for the public law theory is about the democratic deficit prevailing in the international legal process. Using democratic legitimation in the international realm causes inextricable situations in all the legitimation proposals mentioned above. Global constitutionalism provides an illustration of such inadequacy. While constitutions protect the differences between law and politics ${ }^{94}$ and reflect the existence of a set of rules existing above everyday politics, global constitutionalism tends to be apolitical, unless law and politics are considered so "deeply intertwined" that they cannot be conceived separately. ${ }^{95}$ As constitutional law is in its essence a "political law", ${ }^{96}$ replacing such a framework at the international level seems hardly conceivable.

\section{Conclusion}

"Democratic regulation" or "procedural democracy" represents a key element of democracy, but not a sufficient one, according to Pierre Rosanvallon. Westminster democracy embodies and institutionalizes this conflictual dimension as it rests on the rule of the majority and the existence of two competing political parties. Assuming that there is a populist component intrinsic to democracy and that no international or cosmopolitan demos can have a strong feeling of its own identity, then no form of con-

93 Dahl, R. (1999), "Can international organizations be democratic? A skeptic's view” In: I. Shapiro and C. Hacker-Cordón (eds), Democracy's Edges. Cambridge: Cambridge University Press, 19-36, 32.

94 Möllers, C. (2012), “Les Gardiennes d'une séparation : Les constitutions comme instruments de protection des différences entre le droit et la politique", Jus Politicum 7, 1-16, available at http://juspoliticum.com/article/Les-Gardiennes-d-un e-separation-Les-constitutions-comme-instruments-de-protection-des-differences-e ntre-le-droit-et-la-politique-462.html, accessed 11 February 2020.

95 Peters, A. (2009) “Conclusions” In: A. Peters, G. Ulfstein and J. Klabbers (eds), The Constitutionalization of International Law. Oxford: Oxford University Press, 342$352,349$.

96 Avril, P. and Le Divellec, A. (2010), Ecrits de théorie constitutionnelle et de droit politique. Paris: Presses Universitaires de Paris-Nanterre. 
flictual democracy would be conceivable in the international realm. As shows the problematic of a European identity, consensus and conflict appear consubstantial to democracy and yet impossible to combine in any form of international legitimation. The prospects for legitimizing ICTs are, therefore, deeply connected to reflections on transnational or cosmopolitan citizenship.

As for NMIs that can be accountable to their people, the introspection on their democratic legitimacy is challenging but indispensable in times of populism. As any political institution, NMIs have taken political decisions that benefited to certain economic players and harmed others. They have sometimes failed to fulfil their general interest and often became unpopular. Therefore, they should be neither isolated nor dependent from the political process. It could be acceptable to be free from direct political control, but not to be free from public accountability. ${ }^{97}$ It is only by dispelling the illusion that they are composed of distant experts that these agencies could be appropriated by the demos and that "their democratic history" could really start. ${ }^{98}$

98 Rosanvallon, supra note 64, 166. 
